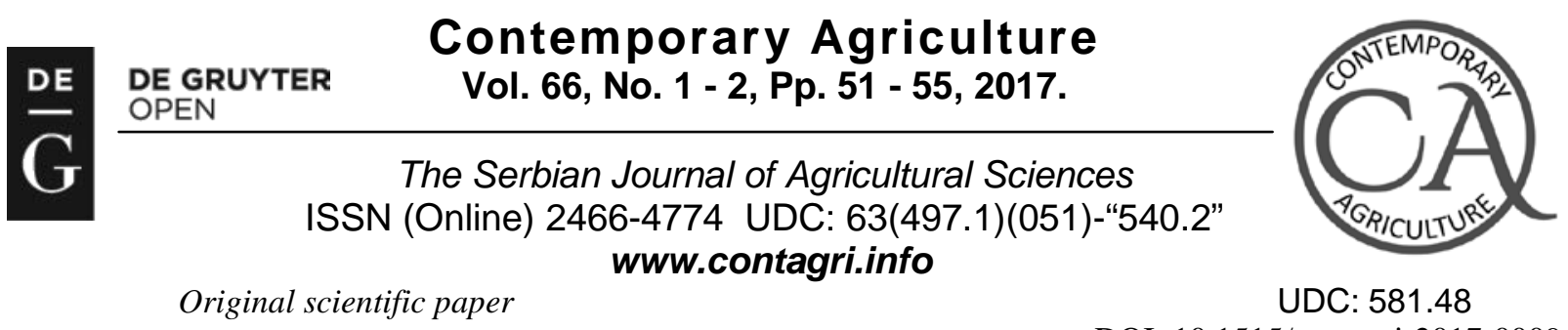

DOI: 10.1515/contagri-2017-0009

\title{
GERMINATION AND RELATIONS BETWEEN SEED QUALITY CHARACTERISTICS FOR ACER PSEUDOPLATANUS AND ACER PSEUDOPLATANUS 'ATROPURPUREUM’
}

\author{
Saša KOSTIĆ், Jelena ČUKANOVIĆ, Mirjana LJUBOJEVIĆ, Emina MLADENOVIĆ, Snežana \\ MRĐAN, Nina SVILOKOS ${ }^{1}$
}

\begin{abstract}
Summary: The purpose of this paper is to analyze relations between seed quality characteristics and the influence of contaminated urban areas on seed quality of sycamore maple trees in different locations across Novi Sad (Serbia). This research analyzed seed germination of 29 adult trees of sycamore maple (Acer pseudoplatanus L.) and its red leaf variety (Acer pseudoplatanus 'atropurpureum' Späth.). Our results indicate a medium strong positive correlation between seed weight and viable seed. Sycamore maple trees from the same urban typology do not have significant influence on seed quality characteristics, while different urban typology has such influence. These results explain the negative influence of urban areas on seed quality characteristics. For selection of high value trees in urbanized and contaminated areas, seed quality can be the indicator of adaptability to stress related conditions.
\end{abstract}

Key words: sycamore maple, germination, seed quality, seed mass, vitality, variability

\section{INTRODUCTION}

Sycamore maple (Acer pseudoplatanus L.) is the most widely spread maple in European forests (Rusanen and Myking 2003; Stejskalova et al., 2014), and a common species in urban areas (Vukićević, 1987). It is often used as a species for street planting, since it is tolerant to polluted soil, air and high level of urbanity (Dožić et al., 2010; Henrik et al., 2015). Most part of sycamore maple population in Novi Sad are the basic species of sycamore maple (Acer pseudoplatanus) and its red leaf variety (A. pseudoplatanus 'atropurpureum' Späth).

The seed of sycamore maple is recalcitrant and without endosperm (Hong and Ellis, 1990; Isajev and Mančić, 2001). The seeds have two types of dormancy: morphological and embryo (physiological). Morphological dormancy is caused by testa and pericarp (Isajev and Mančić, 2001; Stejskalova et al, 2014). Embryo dormancy is the result of reduced metabolic activity and high concentration of abscisic acid (ABA) in the seed (Webb et al., 1973; Kastori, 1984; Pinfield et al., 1989.). To overcome dormancy, the seed should be wet and stratified at $1-5{ }^{\circ} \mathrm{C}$ (Stilinović, 1985; Isajev and Mančić, 2001). The average germination in field is 70-80\% (Stilinović, 1985) or 80-90\% (Isajev and Mančić, 2001). In nursery, the most common way of sycamore maple production is from seeds (Krabel and Wolf, 2013).

Sycamore maple is characterized as highly variable species (Fukarek, 1961; Šijačić-Nikolić et al., 2011). A high level of variability in urban forestry is a result of generative tree productions in nurseries. Morphometric and physiological characteristics of seeds influence germination (Kastori, 1984). Variations in seed weight are positively correlated with variability of seeds (Murali, 1997; Stejskalova et al., 2014). There is a relationship between seed weight and germination, but it differs between species. For maple species, this relationship is positive (Norden et al., 2009; Stejskalova et al., 2014).

The purpose of this paper is to evaluate the influence of seed mass on germination, and to investigate germination capacity and variability of A. pseudoplatanus and A. pseudoplatanus 'atropurpureum' in a laboratory, grouped according to genotype, species, locations and urban typology.

\footnotetext{
${ }^{1}$ Saša Kostić, MSc, PhD student, Jelena Čukanović, PhD, Assistant Professor Mirjana Ljubojević, PhD, Assistant Professor, Emona Mladenović, PhD, Assistant Professor, Snežana Mrđan, MS, Associate, Nina Svilokos, BSc student, University of Novi Sad, Faculty of Agriculture, Trg Dositeja Obradovića 8, 21000 Novi Sad.

•Corresponding author: Saša KOSTIĆ, e-mail: kosticsasa50@gmail.com , Tel.:+38164/3385640
} 


\section{MATERIAL AND METHODS}

The seed material for this analysis was collected from 29 adult trees of A. pseudoplatanus and A. pseudoplatanus 'atropurpureum' on the south side of tree crown. The data were collected from streets and parks across the urban areas of Novi Sad, Republic of Serbia. The sample was divided by genotypes into two parts of 50 and 40 seeds. A part of 50 seeds has been dried for 48 hours at room temperature, and afterwards the seed weight was measured. Other 40 seeds have been placed for stratification for 30 days at $5^{\circ} \mathrm{C}$, and after this period qualitative characteristics of seeds have been tested in a laboratory. The sample has been placed in a thermostat at temperature of $20^{\circ} \mathrm{C}$ for 3 weeks (21 days). Germinated seeds were counted twice a week. Viable seed, non-viable seed and rotten seed were the qualitative characteristics that have been examined. Empty seeds were eliminated prior to the analysis.

For statistical analysis Statistica 12 software (StatSoft, Inc., Tulsa, OK, USA) and SPSS Statistics 23. (IBM, Statgraphics Centurion XVII) were used. Normal data distributions were tested with Kolmogorov-Smirnov and Shapiro-Wilk test, grouped by genotypes and species. For statistical analysis, nonparametric tests Kruskal Wallis test for finding statistical difference and Spearman's correlation were used to analyze power relations and descriptive statistics for the analyzed data. Descriptive statistics was analyzed with range (Rg), minimum (Min), maximum (Max), mean ( $\bar{x}$ ), standard deviation (Std. dev), and coefficient of variations (CV). The data were divided according to urban typology and species. The results were interpreted by Hadživuković (1989) and Stevens (1999), and presented in tables and graphs.

\section{RESULTS}

Descriptive statistics is used for evaluation of seed germination. The data are provided in Table 1 . The results showed different degrees of variability between the analyzed parameters. Average weight of one seed was $0.159 \mathrm{~g}$. Mean $(\bar{x})$ value for the parameter viable seed was 26.034 seeds $(65.08 \%)$, for rotten seed was less than 1 seed and for non-viable seed it was 13.069 seeds (32.74\%). The parameter coefficient of variations (CV) ranged from $26.28 \%$ to $235.38 \%$. The parameters rotten seed and non-viable seed had a higher variability than viable seed and average seed weight. Comparative analysis and test of statistically significant difference (Table 3.) did not show any difference between A. pseudoplatanus and A. pseudoplatanus 'atropurpureum'.

The correlations between the four analyzed characteristics of seed quality are given in Table 2 . The relations between seed weight and viable seed had the strongest correlation $(0.386)$ at the level of $p<0.01$. The relations between seed weight and non-viable seed as well as the correlation between seed weight and rotten seed had slightly smaller values than the previous correlation. All analyzed correlations had medium significance.

Table 1. Descriptive parameters for qualitative characteristics of seeds.

\begin{tabular}{|c|c|c|c|c|c|c|}
\hline & Rg & Min & Max & $\bar{x}$ & Std. dev & CV (\%) \\
\hline Seed weight (g) & 0.212 & 0.096 & 0.308 & 0.159 & 0.042 & 36.13 \\
\hline Viable seed & 38.00 & 0.00 & 38.00 & 26.034 & 9.41 & 26.28 \\
\hline Non-viable seed & 29.00 & 1.00 & 30.00 & 13.069 & 8.362 & 63.98 \\
\hline Rotten seed & 10.00 & 0.00 & 10.00 & 0.897 & 2.11 & 235.38 \\
\hline
\end{tabular}

Table 2. Spearman's correlations between seed weight and 1) viable seed, 2) non viable seed and 3) rotten seed.

\begin{tabular}{|c|c|c|c|c|}
\hline & $\begin{array}{c}\text { Seed } \\
\text { weight }\end{array}$ & $\begin{array}{c}\text { Viable } \\
\text { seed }\end{array}$ & $\begin{array}{c}\text { Non } \\
\text { viable } \\
\text { seed }\end{array}$ & $\begin{array}{c}\text { Rotten } \\
\text { seed }\end{array}$ \\
\hline Seed weight & 1 & $0.386^{*}$ & -0.362 & -0.349 \\
\hline Viable seed & $0.386^{*}$ & 1 & & \\
\hline Non viable seed & -0.362 & & 1 & 1 \\
\hline Rotten seed & -0.349 & & & \\
\hline & $*$ Correlation is statistically significant at the level of 0.05 \\
\hline
\end{tabular}


The dynamics of germination with standard errors was given in Figure 1.B). Monitoring of the germination was performed twice a week. The most intensive germination was between $14^{\text {th }}$ and $17^{\text {th }}$ day, when 302 seeds were germinated, with the average of 10.34 seeds per genotype. Germination was noticed before the first standard counting on $4^{\text {th }}$ day for 6 out of 29 analyzed genotypes. At the second germination counting (day 7) germination started in 28 out of 29 genotypes. One genotype did not start to germinate until day 21, although the seed did not rot or have any pathological changes. The average value of seed germination was 26.03 (65.08\%). Germination higher than mean values was noticed in 17 out of 29 genotypes, germination higher than $80 \%$ in 12 of 29 genotypes and higher than $90 \%$ in 3 of 29 genotypes. The highest germination by genotype was 38 of 40 seeds $(95.00 \%)$.

Scatterplot diagram provided in Figure 1.A) presents the correlation between average seed weight and viable seed. This Figure presents positive correlations between the analyzed factors, but not between species. The data have a concentric arrangement.

Kruskal Wallis test of statistically significant difference between urban typology and species was partially given, for significance of $\mathrm{p}<0.05$ (Table 3.). Kruskal Wallis test did not provide significant differences between the species for all the analyzed parameters, nor between urban typology for average seed weight and rotten seed. Statistically significant difference was noted between urban typology for the parameters of viable seed and non-viable seeds.

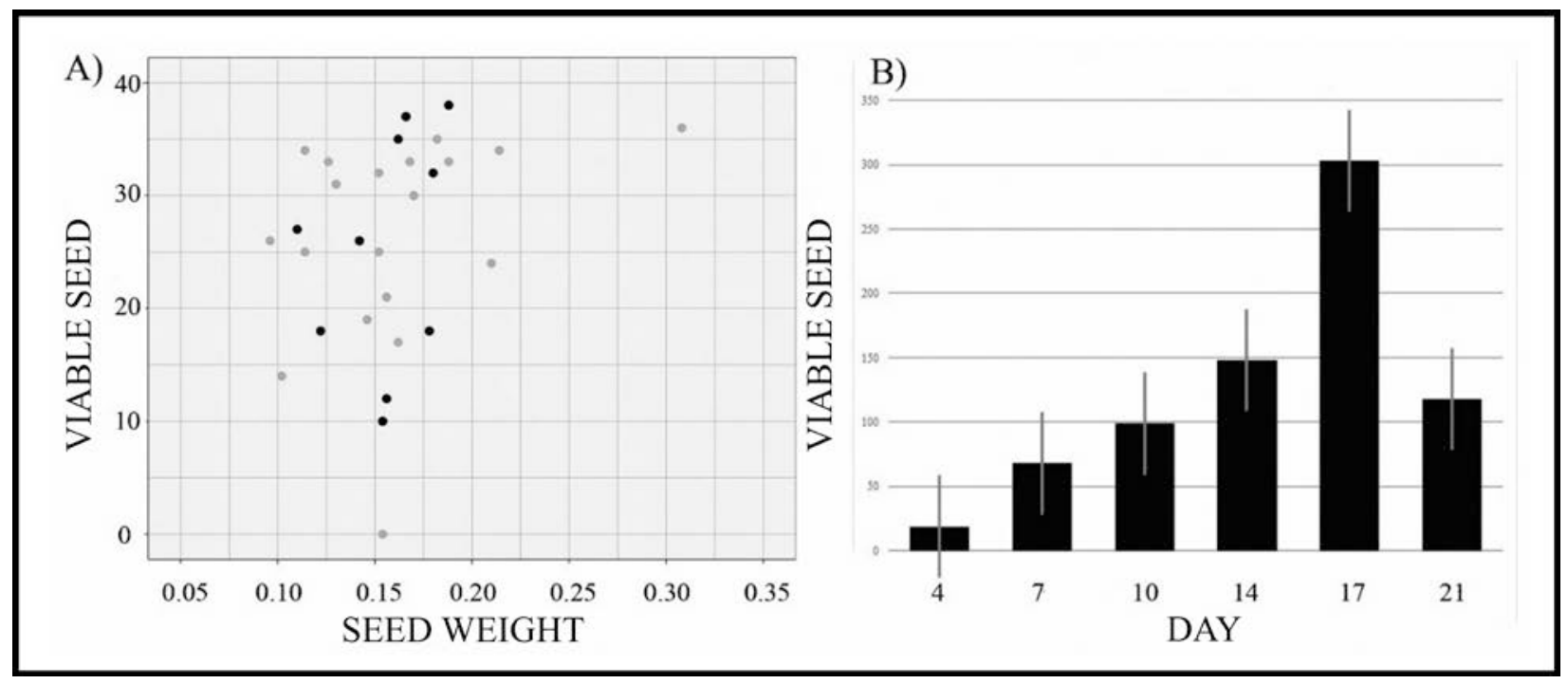

Figure. 1. A) Scatterplot diagram of average seed weight and viable seed

for A. pseudoplatanus (black) and A. pseudoplatanus 'atropurpureum' (gray) B) Dynamics of germination

Table 3. Kruskal-Wallis test of seeds qualitative charasteristics

\begin{tabular}{|c|c|c|c|c|c|c|c|c|}
\hline \multicolumn{5}{|c|}{ Between urban tipology } & \multicolumn{4}{|c|}{ Between species } \\
\hline & 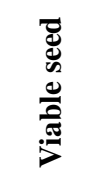 & 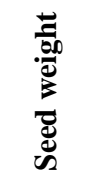 & 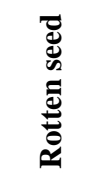 & 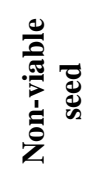 & 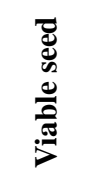 & 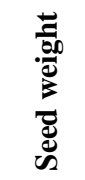 & 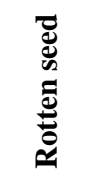 & 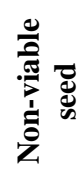 \\
\hline Chi-Square & 5.347 & 0.481 & 0.086 & 5.621 & 0.013 & 0.034 & 0.054 & 0.076 \\
\hline $\mathrm{df}$ & 1 & 1 & 1 & 1 & 1 & 1 & 1 & 1 \\
\hline Asymp. Sig. & $0.021^{\mathrm{a}}$ & 0.488 & 0.769 & $0.018^{\mathrm{a}}$ & 0.909 & 0.854 & 0.816 & 0.783 \\
\hline
\end{tabular}

\section{DISCUSSION}

The analysis shows that there is medium positive correlation between seed weight and viable seed. This result does not comply with theoretical arguments (Louda, 1989, Norden et al., 2009), but many studies had the same results (Moles et al., 2003; Norden et al., 2009). These results of positive correlations can be explained by morphology of testa, water absorption, intensity of gas exchanges (Vazquez-Yanes and Orozco-Segovia, 1993) and different levels of dormancy caused by germination inhibitors (Webb et al., 1973). 
Germination in this study of sycamore maple (A. pseudoplatanus) started early. Seedlings were noted at the first counting of germination on the day 4 , while the majority of seeds germinated in 2 weeks. These results were in accordance with Stejskalova et al. (2014), Gradački et al. (2006) and Pinfield et al. (1989), who analyzed sycamore's germination in a laboratory. Pinfield et al. (1989) concluded that the reason for such fast germination is rapid reduction in the level of ABA after stratification in optimal temperature and water absorption.

The percentage of viable seed suggests that the seeds were of good quality and can be used as an initial material in nursery production. Three genotypes having a germination rate higher than $90 \%$ could be outlined. These high percentages are in accordance with Stejskalova et al. (2014) but not with the basic literature (Stilinović 1985; Isajev and Mančić, 2001). The reason for the lack of germination in one genotype could be dormancy because morphological and anatomical seed characteristics did not show pathological changes or seed dehydration. Seed weight was within the range of the values reported by Stilinović (1985) and Isajev and Mančić (2001).

Results of Kruskal Wallis test showed statistically significant difference of viable seed between urban typology. These results can be explained by negative influence of urban areas on the quality characteristics of seeds. High level of urbanity caused air and soil pollution, more prevalent built structures, pavement and other negative influence on urban forestry. The listed factors cause plant stress, influencing physiological changes and disrupted transport of nutrients into a plant. Stress influence on germination was reported by many authors. Majority of the studies showed that stress has a significant effect on the germination. Kastori (1984), Majid Sharifi and Javad Sharifi (2013) and Begum et al. (2013) analyzed different plants and concluded that there is a negative correlation between plant stress and germination.

\section{CONCLUSION}

The selected genotypes, in average, have a high level of germination, with 3 genotypes achieving germination over $90 \%$. This research should be further investigated in the field conditions in order to fortify the results. The average value of germination was $65 \%$, while the average seed weight was $0.159 \mathrm{~g}$. Species and locations from the same urban typology did not have significant influence on seed qualitative characteristics as different urban typology did. These results explain the negative influence of urban areas on seed qualitative characteristics.

Seed quality can be one of the indicators of stress conditions and a parameter for the selection of high value trees/plus tree/ in urbanized and other types of contaminated areas. The current high variability of seed qualitative characteristics between genotypes provides a good basis for further research in urban populations of sycamore maple.

\section{REFERENCES}

BEGUM M.AJ., SELVARAJU P., VENUDEVAN B.: Saline stress on seed germination, Scientific Research and Essays 8 (30), 1420-1423, 2013.

DOŽIĆ S., ĐUKIĆ M., LUKIĆ S., ĐUNISAJEVIĆ-BOJOVIĆ D.: Reclaimation of the copper mine chatse, International conference degraded areas \& ecoremediation. Belgrade, 392-400, 2010.

FUKAREK P.: Red leaf sycamore maple (Acer pseudoplatanus f. Purpureum Rend.), Narodni šumar 3-4, 1961. (In Serbian, with English summary)

GRADAČKI M., POŠTENJAK K., CRNKOVIĆ S.: Investigation of qualitative properties of the seeds, Rad. Šumar. Inst. Izvanredno izdanje 9, 307-318, 2006. (In Serbian, with English summary)

HADŽIVUKOVIĆ, S.: Statistika, Privredni pregled, Beograd, 1989. (In Serbian)

HENRIK, S., ANDREW, H., NINA, B.: Urban forest resilience through tree selection-Variation in drought tolerance in Acer, Urban Forestry and Urban Greening 14, 858-865, 2015.

HONG T.D., ELLIS R.H.: A comparison of maturation drying, germination, and desiccation tolerance between developing seeds of Acer pseudoplatanus L. and Acer platanoides L, New Phytologist 116, 589-596, 1990.

ISAJEV V., MANČIĆ A.: Šumsko semenarstvo, Šumarski fakultet, Univerziteta u Banja Luci, Šumarski fakultet Univerziteta u Beogradu, Banja Luka, Beograd, 2001. (In Serbian)

KASTORI R.: Fiziologija semena, Matica Srpska, Departman of natural science, Novi Sad, 1984. (In Serbian)

KRABEL D., Wolf H.: Chapter 8. Sycamore maple (Acer pseudoplatanus L.). In: Forest Tree Breeding in Europe: Current State of the Art and Perspectives (PÂQUES E.L. edt.), Springer Science \& Business Media, 373-402, 2013. LOUDA S.M.: Predation in the dynamics of seed regeneration. Ecology of Soil Seed Banks (eds M.A. Leck, V.T. Parker \& R.L. Simpson),. Academic Press, New York, 25-51, 1989.

MAJIDSHARIFI R., JAVADSHARIFI R.: Effects of Abiotic Stress Conditions on Seed Germination and Seedling Growth of Medical Plant, Hyssop (Hyssopus officinalis L.), International Journal of Agriculture and Crop Sciences 5 (21), $2593-2597,2013$. MOLES A.T., WARTON D.I., WESTOBY, M.: Do small-seeded species have higher survival through seed predation than largeseeded species?, Ecology 84, 3148-3161, 2003. 
MURALI, K.S.: Patterns of seed size, germination and seed viability of tropical tree species in southern India, Biotropica, 29, 271-279, 1997.

NORDEN N., DAWS M.I., ANTOINE C., GONZALEZ M.A., GARWOOD N.C., CHAVE J.: The relationship between seed mass and mean time to germination for 1037 tree species across five tropical forests, Functional Ecology 23, 203-210, 2009.

PINFIELD N.J., STUTCHBURY P.A., BAZAID S.A., GWARAZIMBA V.EE.: Abscisic acid and the regulation of embryo dormancy in the genus Acer, Tree Physiology 6, 79-85, 1989.

RUSANEN M., MYKING T.: Euforgen Technical Guidelines for Genetic Conservation and Use for Sycamore (Acer pseudoplatanus). Rome, International Plant Genetic Resources Institute 6, 2013.

ŠIJAČIĆ-NIKOLIĆ M., OCOKOLJIĆ M., VILOTIĆ D., MILOVANOVIĆ J.: The genetic potential of mother trees as a basis for Acer pseudoplatanus ‘Atropurpureum’ plant production, Arch. Biol. Sci. 63 (1), 145-150, 2011.

STEJSKALOVÁ J., KUPKA I., NOVÁKOVÁ O.: Influence of sycamore seed stratifi cation length on their germination capacity, Journal of Forest Science 60 (5), 212-217, 2014.

STILINOVIĆ S.: Semenarstvo šumskog i ukrasnog drveća i žbunja, Univerzitet u Beogradu, Beograd, 1985. (In Serbian)

VAZQUEZ-YANES C., OROZCO-SEGOVIA A.: Patterns of seed longevity and germination in the tropical rainforest, Annual Review of Ecology and Systematics 24, 69-87, 1993.

VUKIĆEVIĆ E.: Dekorativna dendrologija, Naučna knjiga, Beograd, 1987. (In Serbian)

WEBB D.P., VAN STADEN J., WAREING P.F.: Seed dormancy in Acer, changes in endogenous germination inhibitors, cytokinins, and gibberellins during the breaking of dormancy in Acer pseudoplatanus L., Journal exp. Bot. 24(4), 741-750, 1973.

\title{
KLIJAVOST I ODNOSI IZMEĐU KVALITATIVNIH KARAKTERISTIKA SEMENA KOD ACER PSEUDOPLATANUS I ACER PSEUDOPLATANUS 'ATROPURPUREUM'
}

\author{
Saša KOSTIĆ, Jelena ČUKANOVIĆ, Mirjana LJUBOJEVIĆ, Emona MLADENOVIĆ, Snežana MRĐAN, Nina \\ SVILOKOS
}

Izvod: Cilj ovog rada je bio da se analiziraju odnosi između kvalitativnih karakteristika semena i ispita uticaj zagađenih urbanih područja na kvalitet semena gorskog javora, sa različitih lokacija u Novom Sadu (Srbija). Ovo istraživanje analizira seme sa 29 stabala gorskog javora (Acer pseudoplatanus L.) i crvenolisnog gorskog javora (Acer pseudoplatanus 'atropurpureum' Späth.). Rezultat pokazuje srednje jaku poztivnu korelaciju između mase i klijavosti semena. Unutar istih urbanih tipologija nisu uočena značajna odstupanja u kvalitetu semena, za razliku od ove pojave kod različituh urbanih tipologija postoji značajna razlika u kvalitetu semena. Ovaj rezultat objašnjava negativan uticaj urbane sredine na kvalitativne karakteristike semena. Prilikom selekcije visoko vrednih stabala u urbanizovanim i zagađenim područjima kvalitet semena može biti pokazatelj adaptabilnosti na stresne uslove.

Ključne reči: gorski javor, klijavost, kvalitet semena, masa semena, vitalnost, varijabilnost.

\author{
Received / Primljen: 05.04.2017. \\ Accepted / Prihvaćen: 10.07.2017.
}

